\title{
Correction to: Stereotactic body radiation therapy for non-small cell lung cancer patients with prior history of thoracic surgery and/or radiation therapy: the influence of smoking, size, and central location on risk of complications
}

\author{
Jason W. Chan ${ }^{1}$ - Julian Johnson ${ }^{1}$ - Ann A. Lazar ${ }^{2}$ - Steve E. Braunstein ${ }^{1} \cdot$ Martina Descovich ${ }^{1}$. \\ Alexander R. Gottschalk ${ }^{1}$. Sue S. Yom ${ }^{1}$
}

Published online: 23 March 2019

(C) The Author(s) 2019

Correction to: Journal of Radiation Oncology (2018) 7:53-61 https://doi.org/10.1007/s13566-017-0330-7

The article Stereotactic body radiation therapy for nonsmall cell lung cancer patients with prior history of thoracic surgery and/or radiation therapy: the influence of smoking, size, and central location on risk of complications, written by Jason W. Chan, Julian Johnson, Ann A. Lazar, Steve E. Braunstein, Martina Descovich, Alexander R. Gottschalk, and Sue S. Yom, was originally published electronically on the publisher's internet portal (currently SpringerLink) on 10 October 2017 without open access.

With the author(s)' decision to opt for Open Choice the copyright of the article changed on March 2019 to (C) The Author(s) 2019 and the article is forthwith distributed under the terms of the Creative Commons Attribution 4.0 International License (http://creativecommons.org/licenses/ by/4.0/), which permits use, duplication, adaptation, distribution and reproduction in any medium or format, as long as you give appropriate credit to the original author(s) and the source, provide a link to the Creative Commons license and indicate if changes were made.

Open Access This article is distributed under the terms of the Creative Commons Attribution 4.0 International License (http:// creativecommons.org/licenses/by/4.0/), which permits unrestricted use, distribution, and reproduction in any medium, provided you give appropriate credit to the original author(s) and the source, provide a link to the Creative Commons license, and indicate if changes were made.

Publisher's note Springer Nature remains neutral with regard to jurisdictional claims in published maps and institutional affiliations.

The online version of the original article can be found at https://doi.org/ 10.1007/s13566-017-0330-7

Sue S. Yom

sue.yom@ucsf.edu

1 Department of Radiation Oncology, Helen Diller Comprehensive Cancer Care Center, University of California, San Francisco, 1600 Divisadero St., Suite H-1031, San Francisco, CA 94143-1708, USA

2 Department of Preventive and Restorative Dental Sciences, University of California, San Francisco, San Francisco, CA, USA 